\title{
TRANSISI PENYEDIAAN TRANSPORTASI PUBLIK BERBASIS PELAYANAN
}

\author{
ASMUNI \\ Program Studi Ilmu Administrasi Publik \\ Sekolah Tinggi Ilmu Administrasi Pembangunan Jember \\ Email: asmuni.mumun01@gmail.com
}

\begin{abstract}
Abstrak
Transportasi publik merupakan sarana yang erat dengan peradaban. Dimana kompenen dasarnya terkait dengan kondisi sosial, ekonomi dan struktur masyarakat. Di Indonesia, seperti halnya beberapa negara berkembang di Asia sistem transportasi publik terkesan dibiarkan apa adanya. Persoalan-persoalan seperti kemacetan, tingginya kecelakaan dan waktu yang tidak efesian menjadi ciri utama. Pelayanan transportasi publik seperti kereta api atau perbaikan moda transportasi darat merupakan upaya-upaya untuk memuaskan pelanggan dan memberi pilihan kepada pelanggan atau warga negara. Secara umum, perubahan cara pandang tersebut terkait dengan cara pelayanan kepada penggunanya.
\end{abstract}

Kata kunci: Transportasi Publik, Pelayanan Transportasi Publik, Kepuasan Publik dan Pilihan Publik. 


\section{Pendahuluan}

Bagi bangsa-bangsa yang baru merdeka, persoalan transportasi bukan merupakan persoalan yang utama. Isu transportasi yang layak pada hakekatnya masih kalah seksi dari persoalan-persoalan pangan. Sebagai pembenar atas pernyataan di atas, di dunia ketiga yang notabene negara baru merdeka tidak ada satu rezim yang jatuh karena trasnportasi yang buruk. Kejatuhan sebuah rezim acak kali disebabkan oleh ketidakstabilan penyedian pangan. Sebagai contoh, jauhnya rezim Soekarno dan Soeharto di Indonesia, atau Ferdinand Marcos di Filipina _tanpa mengecilkan faktor politik lainya_salah satunya pemicunya disebabkan terpuruknya ekonomi yang juga terkait dengan kebutuhan bahan pokok yang tidak terpenuhi secara layak.

Persoalan transportasi

memperoleh perhatian ketika kemacetan dan kepadatan kendaraan dikeluhkan oleh sebagian masyarakat, terutama perkotaan. Jadi, isu pentingnya transportasi sejatinya masih terbatas pada perbincangan kangalan kelas "menengah perkotaan". Sementara kawasan atau kalangan pinggiran dan pedesaan belum melihat signifikansi keberadaan sistem atau model transportasi yang benar dan baik. Bagi orang-orang pinggiran dan pedesaan persoalan sistem transportasi yang baik masih merupakan kebutuhan sekunder.

Oleh karena itu, menjadi wajar dan masuk akal ketika membahas persoalan transportasi selalu berhubungan dengan persoalan di perkotaan, minimal terkait dengan daerah urban. Bagaimanapun, kotakota besar di negara-negara berkembang kian terasa pengab, kotor dan berjubel. Sebagai pusat ekonomi, politik dan sosial, kotakota besar seperti lentera bagi laron di malam hari atau seperti gula yang didatangi semut. Kota-kota besar telah menarik semua orang, dari semua level masyarakat untuk datang dan berebut nasib di sana. Dari sudut pandang transportasi, dalam beberapa dekade selanjutnya transportasi yang awalnya sederhana menjadi sebuah sistem yang rumet. Transportasi tidak hanya semata alat mengantar orang dari titik A ke titik $\mathrm{B}$, lebih dari itu, transportasi juga terkait dengan kemajuan ekonomi sebuah bangsa. Dalam hal ini (Dridi et al dalam Belwal dan Belwal 2010:2) mengambarkan kondisi transportasi sebagai berikut: In an urbanized society, an efficient transportation system is one of the basic components of the social, economic, and physical structure, and it has to be competitive and attractive to the transit seekers. Dridi ingin menjelaskan bahwa bagi masyarakat urban, transportasi merupakan salah satu kompenan dasar yang tidak bisa dipisahkan dengan kondisi sosial, ekonomi dan psikologi dari struktur masyarakat (publik). Oleh karena itu transportasi akan menjadi sebuah kondisi yang kompetitif dan antraktif orang-orang mempunyai mobilitas tinggi dalam 
memenuhi kebutuhan hidupnya. Secara otomatis, transportasi bisa dilihat sebagai penyangga setidaknya penupang bagi gerak laju perekonomian.

Sementara itu arus globalisasi juga berdampak pada transportasi. Era sekarang, transportasi bukan lagi hanya menjadi faktor pelangkap melainkan faktor determinan bagi keberhasilan pembagunan suatu negara. Dimana Gerak laju pembagunan seperti investasi, perdagangan akan dipengaruhi oleh sistem transportasinya. Singkatnya, semakin baik sebuah transportasi sebuah negara semakin maju pula negara tersebut.

Transportasi merupakan urat nadi bagi setiap aktivitas manusia modern. Seperti yang diungkapnya oleh (Morlock dan Bruton dalam Buku Putih Transportasi, 2006:1) "......advances in transport have made possible changes in the way we live and the way in which societies are organized, and there by have influenced the development of civilization, ". Pendapat tersebut menjelaskan bahwa transportasi sedikit banyak akan mempengaruhi perkembangan sebuah peradaban. Dengan transportasi yang nyaman, aman dan terjangkau memungkinkan orang untuk berubah. Sepertinya, menghubungkan antara kenyamanan transporasi dengan pertumbuhan ekonomi sedikit dipaksakan. Tetapi pada kenyataanya, pertumbuhan ekonomi sebuah kawasan selalu ditandai sarana transportasi yang memadahi. Oleh karena itu, Banyak pihak yang beranggapan transpotasi akan memberikan_sedikit rasa aman bagi para investor untuk melakukan investasi pada suatu negara atau daerah. Dampak selanjunya adalah dengan investasi tersebut akan memacu sektor-sektor ekonomi yang lain di sekitarnya.

Pertumbuhan suatu kawasan, dengan sendirinya pula akan meningkatkan mobilitasnya warga untuk mengejar kehidupan yang dianggap lebih baik. Dalam konteks seperti ini, trasportasi yang memadahi menjadi layak untuk dibicarakan. Dari sudut pandang kajian publik, keberadaan transportasi yang nyaman dan aman serta terjangkau merupakan bagian tak terpisahkan dari kewajiban pemerintah memberikan pelayanan kepada warganya. Dengan kata lain, transportasi yang baik sangat penting untuk disediakan oleh pemerintah.

Dalam konteks kebutuhan publik, transportasi merupakan sesuatu yang tidak terelakkan dalam menjaga mobilitas publik. Seperti pendapat Dridi di atas, bahwa bagi masyarakat, terutama masyarakat urban, transportasi merupakan salah satu kompenan dasar yang tidak bisa dipisahkan dengan kondisi sosial, ekonomi dan psikologi dari struktur masyarakat (publik). Oleh karena itu transportasi akan menjadi sebuah kondisi yang kompetitif dan antraktif orang-orang mempunyai mobilitas tinggi dalam memenuhi kebutuhan hidupnya.

Dengan kata lain, untuk menuju mobilitas tersebut 
masyarakat selalu mendesak penyelenggara negara dalam hal ini pemerintah untuk menyediakan moda angkutan umum yang memadahi. Masyarkat juga berharap adanya varian angkutan. Dimana, masyarakat mempunyai pilihan lebih banyak untuk menggunakan transportasi sebagai alternatif. Secara mendasar, yang dibutuhkan adalah anggkutan massal yang mampu mengangkut sebanyak mungkin orang dari satu tempat ke tempat lain. Negara Indonesia merupakan salah satu dari banyak negara berkembang yang lamban dalam menyediakan angkutan massal dibandingkan laju peningkatan kendaraan pribadi. Padahal, penyediaan transportasi bukan hanya berhasil dilakukan oleh negaranegara yang telah maju. Sebagai contoh, negera berkembang seperti Mexico mampu melahirkan transpotasi massal seperti Bus Rapit Transit (BRT) system pada tahun 2005 mampu menghilangkan banyak colectivos_semacam angkutan dengan bak terbuka dengan gas emisi yang tinggi_ di kota-kota metropolitan atau yang lebih dikenal dengan Mexico City Metropolitan Area (MCMA), seperti Distrito Federal (DF) dan Estado De Mexico (EM) dimana keberadaan colectivos tersebut telah hadir di Mexico sejak tahun 1970-an. Keberhasilan transportasi massal seperti BRT dijelakan (Piters, 2011:42) sebagai berikut, Since the city government implemented the BRT model in DF, the government has permanently removed 839 colectivos operating in the MCMA area.

Keutamaan BRT system juga terletak dari daya tampungnya yang sangat besar terhadap perpindahan banyak orang dari satu kawasan ke kawasan lainnya. Daya tampung BRT system dituturkan (McKone dalam Piters, 2011:44) Today, the Metro bus system transports 620,000 passengers per day and results in a reduction of an estimated 100,000 tons of carbon dioxide emissions every year.

BRT system merupakan kebijakan transpotasi yang dilakukan pembuat kebijakan kota. BRT sistem menggunakan metrobus hanya beroperasi didalam kota, bisa mengangkut penumpang sampai 620.000 orang per-hari. Untuk waktu dekat, bagi negara seperti Mexico BRP merupakan jawaban atas persoalan transportasi dalam kota. Dan sebagai bonusnya adalah berkurangnya gas emisi karbon yang sebanyak 100.000 ton karbon dioksida setiap tahunnya. Pengurangan gas buang tersebut dapat dimengerti karena dipensiunkannya colectivos yang terkenal dengan asap pekatnya.

Di sisi lain, transpotasi massa juga terkait dengan kesadaran (awareness) publik untuk menjaga aset dan semua perlengkapan transportasi dari jalan raya, trotor, rel kereta, stasiun, bus, kereta. Karena keberadaanya merupakan katagori barang publik (public good). Dimana keberadaaanya, tidak diperuntukkan kepada orang per-orang tetapi kepada 
kepentingan orang banyak. Dalam hal ini (Rachbini, 2006: 50-51) memandang barang publik sebagai barang atau jasa yang tidak bisa dikonsumsi atau digunakan secara individu semata, karena mempunyai pengaruh terhadap individu yang lain dalam suatu kelompok.

Hal yang kontras terjadi di negara berkembang. Infrastruktur yang belum memadahi, tingkat kemacetan yang tinggi, suasana yang berjubel di dalam transportasi umum menjadi sajian yang terjadi setiap hari. Di negara berkembang, lalu lintas merupakan perjalanan yang mengandung resiko keselamatan yang cukup tinggi atau mempunyai tingkat keamanan yang rendah. Menurut data Kepolisian Republik Indonesia sampai kuartel ketiga tahun 2011 ada sebanyak 4.744 kecelakaan lalu lintas, melibatkan 6.280 kendaraan. Mayoritas kendaraan roda dua atau sepeda motor dan menewaskan 779 jiwa. Jumlah ini meningkat hampir 30 persen dibandingkan tahun sebelumnya yang berjumlah 3.639 laka dan melibatkan 4.532 kendaraan. Diperkirakan, jumlahnya terus meningkat setiap tahun. (www.pikiran-rakyat.com. 14/03/2012)

Data yang kurang lebih sama dikeluarkan oleh Fraksi PKB DPRRI. Menurutnya, Sampai 2011 tercatat 106.129 kecelakaan lalulintas yang terjadi di seluruh Indonesia. Korban jiwa meninggal mencapai 30.629 jiwa, luka berat 35.787 dan luka ringan 107. 281. Sementara, kerugian materil diperkirakan mencapai Rp 278,432 miliar. (http://www.republika.co.id. 09/02/12)

Data di atas menunjukkan bahwa tingkat kecelakan lalu lintas di Indonesia masih cukup tinggi. Ada beberapa alasan mengapa tingkat kecelakaan di Indonesia cukup tinggi, salah satunya adalah kerusakan jalan. Menurut (Munawar, 2007:04) kerusakan jalan yang menyebabkan timbulnya biaya ekonomi dan biaya sosial yang besar. Kondisi jaringan jalan nasional berada dalam kondisi kritis, selain karena kurangnya anggaran melalui APBN, juga karena sejak sebelum krisis pembinaan, pelaksanaan dan pengawasan pelaksanaan pembangunan jalan yang berkualitas belum prima.

Dengan rusaknya jalan, bukan hanya membuat perjalan tidak nyaman, tetapi juga menghambat aksesbilitas seseorang dalam menggunakan jalan tersebut. Boleh dikata, bahwa tingkat kecelakan itu disebabkan oleh kerusakan jalan yang berakibat orang menjadi resah dalam perjalanan. Disisi lain, banyak armada transportasi yang memiliki tingkat kelayakan rendah. Transportasi publik dioperasikan dengan ala kadarnya. Kebanyakan transportasi publik, terutama transpotasi darat memang menanggung beban biaya operasional yang cukup tinggi. Kendaraan publik baik yang dikelolah oleh pemerintah ataupun yang dikelolah oleh pihak swasta 
memiliki ciri yang sama yaitu usang dan kanibalis. Tindakan tersebut terjadi untuk mensiasati tingginya biaya operasional.

Lebih lanjut (Munawar 2007:03) menjelaskan tentang kondisi transportasi publik dalam melakukan operasinya:

Dari segi sarana transportasi darat, terjadi penurunan jumlah armada operasi yang disebabkan oleh kenaikan harga suku cadang, kenaikan biaya modal yang diakibatkan kenaikan suku bunga karena kenaikan kurs dollar serta persaingan dengan moda transportasi lain (terutama transportasi udara), sehingga menyebabkan biaya operasi kendaraan menjadi tinggi, sedangkan kenaikan tarif relatif rendah, karena daya beli masyarakat yang rendah.

Dari pendapat di atas, dapat dijelaskan lebih lanjut bahwa persiangan dalam transportasi lebih kepada kemampuan dari penyelengara yang gagal beradaptasi dengan gerak laju publik, terutama di daerah perkotaan dan urban. Dengan kata lain, dalam hal pelayanan transportasi publik, pemerintah gagal dalam memberikan pelayanan yang maksimal dan kepuasan publik cukup terganggu dengan adanya hal tersebut. Pesatnya sistem perkreditan merupakan asumsi bahwa sejatinya masyarakat tidak puas dengan pelayanan transportasi yang ada di negeri ini. Penggunaan kendaraan pribadi_ yang diperoleh dari kemudahan sistem perkreditan_sedikit-banyak telah mengurangi "ketergantungan publik" terhadap trasnportasi publik, terutama untuk tujuan trayek pendek dan menengah. Bagi publik, kendaraan pribadi baik sepeda motor ataupun mobil merupakan alternatif lain dalam berkendara. Tetapi hal tersebut juga menjadi bukti_setidaknya sebagai petanda_ bahwa pelayanan transportasi publik di negera ini mempunyai problem yang sangat pelik.

Kompleksitas masalah keberadaan transportasi publik memaksa _paling tidak memikirkan_ pemerintah untuk memikirkan ulang hubungan dari beberapa pemangku kepentingan terhadap timbulnya kompleksis transportasi publik. Problem transportasi publik tidak hanya tercipta oleh kualitas yang rendah dari penyedia jasa transportasi baik yang disediakan pemerintah maupun pihak swasta, terlebih tumbuh pesatnya marketable kendaraan pribadi. Harus diakui bahwa penyedia layanan transportasi yang lemah telah memicu meledaknya jumlah kendaraan pribadi. Oleh karenanya, menjadi penting untuk melihat kembali kebijakan yang ada terutama dalam misi pelayanannya, bahwa kompleksitas persoalan yang menyebabkan rendahnya pelayanan harus diintegrasikan pelayanannya. Menurut (Kettl dalam Osborne hal 247) menjelaskan tentang integrasi 
layanan (service integration, sebagai berikut:

"The complexities of these systems have increasingly led governments to rely on service integration

contractors. Instead of purchasing goods and services directly from suppliers, government contracts with a general contractor, who in turn contracts out with other suppliers for the production of the good or service. In many cases, the service integrator is responsible not only for general oversight of the project but also for designing many of its keyelements.

Jika merujuk pada UU No. 22 tahun 2009 tentang keselamatan lalu lintas dan angkutan jalan bab 1 menjelaskan tentang keselamatan lalu lintas adalah sebagai suatu keadaan, dimana setiap orang terhindar orang dari resiko kecelakaan selama berlalu lintas yang disebabkan oleh manusia, kendaraan, jalan dan/atau lingkangan. Tentu saja, banyak faktor yang menyebabkan terjadinya kecelakaan tetapi faktor yang cukup dominan bisa saja terletak pada kondisi jalan yang kurang memadahi. Volume kendaraan bermotor terus meningkat setiap tahunnya, sementara luas dan panjang jalan belum bertambah. Ditambah faktor lingkungan seperti banjir ataupun tanah longsor yang memaksa kondisi jalan menjadi rusak.

Persoalan yang terjadi, pilihan untuk menggunakan kendaraan pribadi atau trasnportasi umum sejatinya bukan tergantung pada tingkat pendapatan seorang. Tetapi lebih karena keterbatasan armada yang nyaman dan aksestable bagi setiap individu. Jika transportasi publik itu accessibility, comfortable dan safety, bagi publik ada kemungkin yang cukup besar untuk lebih menggunakan transportasi publik.

Dengan demikian, transportasi di Indonesia sampai saat ini masih menjadi perhatian banyak kalangan, terutama dalam hal keselamatan. Penyebab utamanya adalah tingkat kecelakaan yang cukup. Menurut Departemen Perhubungan, setidaknya ada tiga hal yang menjadi isu tentang keselamatan transportasi jika dihubungkan dengan kecelakaan, diantranya isu sumber daya manusia (human resources issues,), isu fasilitas (facility issues) dan isu infrastruktur (infrastructure issues) http://www.dephub.go.id/). Isu sumber daya manusia lebih mengacu pada kurang profesionalan dari aparat dan keterbatasan alat dan perlengkapan dari armada transportasi yang ada. Sementara mengenai infrastruktur selalu terkait dengan keberadaan jalan yang kurang memadahi.

Ketiga isu tersebut merupakan lingkaran setan yang harus diurai supaya arah 
pembagunan transportasi publik menjadi jelas sasaran, target dan tujuannya.

Bagaimapun pengembangan trasnportasi publik harus memenuhi standar keamanan (keselamatan) dan kenyamanan. Banyak pihak menilai pemerintah saat ini kurang begitu serius dalam melakukan kebijakan transportasi khususnya transpotasi darat. Ini terlihat dari pola kebijakan yang parsial atau tidak menyeluruh. Di banyak tempat persoalan di tanah air kurang lebih sama, tetapi penangan khususnya terkesan tidak sama. Sebagai contoh kemacetan yang terjadi di Jakarta dan Surabaya merupakan fenomena yang relatif sama, secara logika penanganan pun tidak begitu berbeda. Jika Pemerintah Daerah Istimewa Jakarta menggunakan comuter dan Busway untuk mengurangi kemacetan, sejatinya kebijakan tersebut juga diberlakukan di Surabaya tanpa harus menunggu sepadat Jakarta.

Kebijakan yang cenderung parsial tersebut berbeda dengan pijakan normatif yang dimiliki Departemen Perhubungan sebagai penanggujawab utama transportasi di negara ini. Dalam pandangan normatifnya transportasi, termasuk darat merupakan sebagian dari pembangunan transportasi secara keseluruhan dan merupakan bagian tidak terpisahkan dari pembangunan nasional. Pembangunan transportasi dilaksanakan sebagai dukungan terhadap pembangunan nasional yang berkelanjutan dengan memperhatikan beberapa aspek yang meliputi pembangunan ekonomi dan investasi, keadilan (equity) serta keamanan dan keselamatan. Ketiga aspek tersebut diwujudkan dalam kebijakan dan kerangka kerja regulasi yang dalam operasionalnya diwujudkan dengan instrumen dan pendekatan. Sebagai masukan dalam penyusunan instrumen dan pendekatan tersebut adalah tingkat permintaan untuk mobilitas dan dampak lingkungan yang dihasilkan (Masterplan Darat Bab 1, 2005:5).

Dalam artikel ini ingin menggambarkan tentang kompleksitas persoalan transportasi publik di Indonesia, dari segi kualitas pelayanan, kepuasan penggunannya dan kemugkinan pilihan-pilihan rasional bagi pengguna pelayanan transportasi publik dengan teori-teori public service dan pilihan publik (public choice). Disamping itu, juga penting untuk melihat keunikankeunikan pengelolaan dan pelayanan transportasi serta kendala yang merintangi ketika teori yang ada dibenturkan dengan realitas yang ada.

\section{Metode Penelitian}

Untuk menganalisa dan menjelaskan permasalahan yang telah dipaparkan, penulis menggunakan metode kualitatif dengan jenis penilitian deskriptifanalitis, yaitu menggambarkan faktafakta yang ada dengan menganalisa dan menginterpretasikan data-data yang telah terkumpul. Penelitian ini merupakan penelitian kualitatif. Moleong (2006:112) mengemukakan 
"sumber data utama dalam penelitian kualitatif ialah kata-kata dan tindakan selebihnya adalah data tambahan seperti dokumen dan lain-lain". Lebih lanjut Metodologi kualitatif sebagai prosedur penelitian yang menghasilkan data deskriptif berupa kata-kata tertulis atau lisan dari orang-orang dan perilaku yang dapat diamati. Selain itu, data tersebut juga bisa berasal dari naskah wawancara, catatan lapangan, foto, videotape, dokumen pribadi, catatan atau memo, dan dokumen resmi lainnya. Pengumpulan data yang penulis lakukan adalah dengan memanfaatkan data-data sekunder yaitu melalui library research diantaranya bersumber dari bukubuku, jurnal-jurnal, dokumen, media massa, dan internet. Data kemudian dianalisis dan dituangkan dalam bentuk hasil penelitian di dalam karya ilmiah ini.

\section{Pelayanan dan Kepentingan Publik}

Dalam kajian pelayanan publik (public service), dimulai dengan kritik secara tajam terhadap kegagalan penyelenggaraan pemerintahan dalam memberikan pelayanan secara maksimal kepada warga negaranya. Dalam hal ini, pemerintahan dianggap tidak efektif dan efesien. Pemerintah dianggap lambat, dan tidak sensitif terhadap perubahan lingkungan yang ada. Pemerintah dianggap berjalan atas perlindungan subsidi, proteksi ekonomi, politik, serta transparansi yang sangat minim. Seharunya untuk melihat keberhasilan pemerintah tidaklah cukup hanya dilihat dari satu term seperti kepuasaan pemerintah semata tanpa melihat kepuasan yang lebih besar yaitu kepuasan publik. Pemerintah mempunyai standar keberhasilan tetapi tidak tunggal, dengan kata lain harus melibatkan agen sektor privat atau sektor non profit seperti lembaga swadaya masyarakat atau pemerhati masalahmasalah kebijakan seperti dijelaskan (Stoker, 1998:17 dalam Milward dan Provan, 2000:360) tentang governace:

Governance is amore inclusive term, concerned with creating the conditions for ordered rule and collective action, often including agents in the private and nonprofit sectors as well as within the public sector. The essence of governance is its focus on governing mechanisms (grants, contracts, and agreements) that do not rest solely on the authority and sanctions of government.

Dengan semakin kompleknya persoalan-persoalan publik, menjadi kurang relevan jika pemerintah melakukan secara sendirian seperti yang dibicarakan dalam banyak kesempatan pada waktu lampau. Sebab, dalam banyak hal, permerintah diwaktu lampau, dengan paradigma the old public administration dianggap masih sangat lamban, bahkan cenderung 
abai dalam merespon berbagai kebutuhan dan keluhan warganegaranya. Dengan kata lain, pemerintahan dengan gaya lama tersebut belum mampu menjadi pelayan bagi tuntutan warganegaranya.

Dengan demikian, kritik terhadap gaya pemerintah yang jauh dari pelayanan tersebut menyeruk sekitar dua dekade yang lalu. Misalnya, apa yang disebut oleh Osborne dan Gaebler sebagai reinventing goverment, yang dalam bahasa kita diterjemahkan dengan wirausaha birokrasi. Secara sederhana, pemikiran ini berangkat dari keadaan pemerintah yang dinilai mempunyai problem yang akut, bahkan dari satu pemerintah kepada pemerintah yang lain. Dari sistem satu sistem publik ke sistem publik yang lain.

"our goverment are in deep trouble today. In government after goverment and public system after public system, reinventing is the only option left. But the lack of a vision_a new paradigm_hold us back. "(Osborne dan Gaebler dalam Cullen dan Chusman, 2000:01) Pendapat di atas, dapat ditafsirkan dengan sangat sederhana bahwa problem yang dialami sebuah pemerintahan acapkali sangat mendasar sehingga solusinyapun tidaklah muda. Bahkan ketika pemerintahan itu berganti dan banyak sistem baru dilakukan, problem pemerintahan ternyata tidak kunjung teratasi. Oleh karena itu,
Osborne dan Gaebler mengarisbawahi bahwa reinventing hanya sebagai salah satu opsi yang ditawarkan (the only option left). Secara umum, pendekatan ini melihat pemerintahan harus melakukan usaha seperti cara-cara yang dilakukan oleh pasar (market). Didalamnya, juga menjungjung tinggi semangat persaingan seperti layaknya persaingan sempurna di sektor swasta sehingga penyelenggara pemerintah akan berlomba untuk meningkatkan pelayanan.

Diskursus mengenai perubahan cara melakukan usaha seperti yang dilakukan swasta tersebut yang dikenal dengan new public management, reinventing atau state modernization dan reform mengharapkan sebuah era pada pemerintahan yang merangsang atau mendorong (incentives), kompetitif (competition) dan melaksanakan dengan baik (performance) sebuah pelayanan. Dimana hal tersebut harus diarahkan pada usaha untuk mengganti pemerintahan yang berjenjang (hirarkis) menjadi sebuah institusi yang merepresentasikan demokrasi. Dalam artinya, sesuai dengan kehendak atau kepentingan publik. "...by many to be displacing tradisional public administration's reliance on rulebased hierarchies overseen by the institutions of representative democracy, a development with profound implications for democracy itself. (Lynn, 2006:02). 
Dengan bahasa yang lain, misalnya (Andrisani dan Hakim, 2002:05) mengambarkan tradisional public administration sebagai the era of big goverment is over. The word has learned that goverment are omnipotent. Sejalan dengan pendapat di atas, bagaimanapun dalam dunia yang semakin terhubung satu dengan yang lainnya, sebuah pemerintahan yang mengatur dengan kaku serta tidak melimpahkan kewenangannnya pada institusi-institusi lain sudah tidak laku lagi. Pendapat ini melihat arus tuntutan terhadap pemerintahan yang felksibel sangat tinggi. Today's enveroment demands institutions that are extremely flexibel (Osborne dan Gaebler, 1992:17 dalam Martin,2000:14). Pemerintahan tidak sanggup menyerap tuntutan dari warganegaranya, akan seperti gajah yang berlajan lambat atau seperti tubuh yang besar dan kegemukannya. Dimana gerakanya lamban, dan sangat mungkin menderita sakit.

Tetapi kritik pun muncul terhadap konsep pembaharuan ini, baik itu new public management, reinventing atau state modernization, dan new public service terutama dari sarjana yang berhaluan kiri. Pertanyaan yang paling mendasar sejatinya terletak pada dalam konsep melayani? Siapakah itu costumer? Apakah konsep costumer sama persis seperti hukum pasar memperlakukannya.

Konsep melayani dalam kontek pasar selalu berkonotasi dengan kemampuan "membeli" dari seseorang atau individu. Dalam pandangan pasar tidak ada hal yang gratis, semuanya harus dibeli terlebih dahulu baru kemudian ada pelayanan. Atas kritikan tersebut Aliran new public management atau new public service, bukannya tidak menyadari bentuk mekanisme pasar terhadap kepentingan publik makanya pendekatan ini selalu menggaris bawahi hanya sebatas mengadopsi prinsip-prinsip pasar (adopting market principles) (Andrisani dan Hakim, 2002:06) tanpa melupakan tujuan utama negara yaitu menciptakan kesejahteraan dan keadilan yang sebesar-besarnya.

Begitu peliknya hubungan antara pelayanan yang melibatkan individu-individu terkait dengan banyak kepentingan yang menyelimuti keberlasungan antara pelayanan dengan warganegaranya. Kepelikan tersebut logis sebab costumer mempunyai kepentingan yang berbeda-beda, yang dalam kacamata new public management atau new public service paradigm disebut sebagai publik. Dengan kata lain, paradigma tersebut memang mencoba mendefinisikan tentang kepentingan publik (public interest) sebagai wanana untuk dilayani.

Dalam kacamata new public service kepentingan publik dipandang sebagai hal yang harus dilayani. Menurut (Denhardt dan Denhardt, 2003: 79) menjelaskan kepentingan publik;

"The New Public Service also rejects the idea that the 
public interest can be understood as the aggregation of individual self-interests. In the New Public Service, the goal is to move beyond self-interest to discover and act upon shared interests - the public interest. Pelayanan publik mutahir (the new public service) juga menolak idea bahwa kepentingan publik dimengerti sebagai kumpulan dari kepentingan individuindividu. Dalam The new public service, tujuannya melampaui kepentingan individu itu sendiri untuk digali dan dilakukan sebagai kepentingan bersama- hal tersebut yang dikatakan sebagai kepentingan publik".

Sebagai otokritik dari berjalanya pelayanan yang bertumpuh terhadap customers _seperti yang terjadi pada new public management_ dimana kepentingan publik diidentifikasikan sebagai market like arenas of choice in which individuals, as customers, can make decisions based on their own selfinterest (Denhardt dan Denhardt, 2003:76). Ini artinya kepentingan publik itu sendiri ketika ditelusuri tidak lebih didasari dari kepentingan pribadi. Oleh karena itu New Public Service menolak klaim tersebut, bagi paham ini pemerintah sebagai penyedia layanan memberikan aturan yang mendasar dan penting yang mendorong atau membantu warga negara melakukan artikulasi kepentingan publiknya. Sebaliknya nilai-nilai bersama dan kepentingan warga negara secara kolektif digunakan sebagai panduan perilaku dan pengambilan keputusan dari penyelenggara pemerintahan.

Jadi, persoalan pelayanan tidak hanya fokus atau dimiliki pada sektor privat tetapi juga bisa diterapkan pada model-model governance. Governance model menurut (Osborne and Gaebler 1992, Koppenjan and Klijn, 2004 dalam Farneti, Padovani and Young dalam Osborne, 2010: 257) It is being used in efforts to transform governance into more effective and effecient that can do more with less. Bahwa transformasi governance memungkinkan untuk menggunakan model-model governance sesuai dengan model futuristik tanpa menghilangkan model yang ada. Beberapa model yang ada seperti Prosedural governance, corporate governance, market governance atau network governance mempunyai peran masing-masing sesuai dengan konteksnya.

Dalam prespektif yang lain, Buchanan mengaris bawahi tentang kemugkinan pilihan yang lebih variatis meskipun itu menyangkut kepentingan publik sekalipun. Dalam pandanganya, publik harus punya pilihan untuk memilih. Pilihan tersebut diasumsikan sebagai wahana tawar-menawar tak ubahnya pasar. Realitas menunjukkan bahwa pelayanan atau kebijakan atas nama publik (masyarakat) tidaklah seperti 
hukum yang berlaku, seringkali kebijakan tersebut menyimpang. Menurut (Buchanan 2009:11), public choice of theory hadir untuk mendiskripsikan secara akurat tentang romantica _suatu anggapan bahwa politik sebagai seni_dan kepura-puraan dari perangkat kebangsaan lewat pemerintah dan para gubenurnya (pejabat pemerintah, penulis) dan perilaku individu-individu dalam pemerintahan yang telah membuat skiptis banyak pihak tentang apa yang akan dilakukan pemerintah atau apa yang akan dilakukan para pejabat (what goverments can do and what govenors will do)? Tentu saja kita harus lebih konsisten _ lebih jujur_dengan realitas politik, bahwa para pejabat pemerintah juga mempunyai kepentingankepentingan sendiri).

Menurut Buchanan, public choice of theory melihat sebuah realitas tersebut. Sehingga, teori ini merupakan teori dalam bidang pemerintahan yang disandingkan secara menyeluruh dengan teori dibidang ekonomi, khususnya teori ekonomi kesejahteraan (the theorical welfare economic).

Buchanan berangkat dari pemikiran tentang kegagalan penyelengara di sektor publik dan sektor private. Menurutnya, "...the system of private markets was shown to "fail" in certain respects when tested againts the idealized criteria for efficiency in resource allocation and distributtion. Goverrment or polical organization is shown to fail in certain respects when tested for satisfaction of idealized criteria for efficiency dan equity (Buchanan,2009:11-12).

Pada satu sisi, private market (pasar swasta) menunjukkan kegagalnya ketika dites dan diperbandingkan kreteria yang ideal yaitu efesiansi untuk alokasi sumber daya dan distribusi ekonomi. Artinya pasar juga tidak menunjukan efesiensi, dan sumber daya hanya dikuasasi segelintir orang saja. Pada sisi lain, pemerintah juga gagal memberikan kepuasan dalam hal efisiensi dan keadilan seperti banyak kreteria dalam tujuan pemerintahan.

Menurut public choice of theory secara esensi adalah pendekatan yang menggunakan alatalat dan metode-metode dalam membangun berdasarkan pengalaman yang sering digunakan pada level di teori ekonomi. Cara dan metode yang sama juga diaplikasikan dalam bidang politik atau sektor pemerintahan, ilmu politik atau ekonomi publik. Public choisce of theory essentially (Buchanan 2009:13) takes the tools and methods of approach that have been developed to quite sophisticated analytical levels in economic theory and applies tools and methods to the political or govermental sector, to politics, to public economic.

Dengan menggunakan pendekatan ekonomi tersebut, public choice of theory berusaha melakukan analisa dalam menghubungkan perilaku dari individu aktor-aktor dalam sektor pemerintahan, atau 
perilaku individu-individu dalam kapasitas sebagai pemilih, kandidat jabatan publik, anggota dewan, pemimpin dan anggota partai politik dari sudut ekonomi. Dengan kata lain, apa yang terjadi di lingkaran pemerintahan, para aktornya sejatinya mempunyai kepentingan sendiri-sendiri.

\section{Politik Exchange}

Dalam banyak hal, sejatinya banyak komparasi antara ilmu politik dan teori economi adalah sederhana saja. Intinya, proses perubahan politik (politic exchange) sangat dibutuhkan untuk menjelaskan perilaku aktor publik dan kepentingan-kepetingan dari perilaku-perilaku individu publik yang ada. Menurut (Buchaman, 2009: 14) setidaknya ada dua hal alasan mengapa hal tersebut diperlukan. Pertama,bahwa politik exhange merupakan konsep kesepakatan yang memasukkan interaksi ekonomi kedalam suatu peraturan hukum yang lebih jelas. Dengan seperti itu, perdagangan dan jasa dalam rana publik akan menjadi rumusan yang legal. Kedua, merumuskan secara baik dan pemfungsian dari legal order tersebut menjadi sangat penting, sehingga diperlukan semua pihak untuk turut andil didalamnya.

Teori pilihan publik (public Choise) merupakan pengembangan dari teori pilihan rasional. Dimana terori pilihan rasional ini lebih digunakan untuk menjelaskan perilaku politik, dengan beberapa konsep utama seperti kesukuan (preferensi), kepercayaan (beliefs), peluang (opportunities) dan tindakan (action). Menurut (Deliarnov,2006: 135) dari semua konsep utama tersebut pilihan rasionalnya adalah perangkingan.

Dengan menggunakan pilihan rasional, akan dipahami rasional politik dalam pemilihan. Dimana sebelum menentukan pilihan, masyarakat melakukan intrepretasi politik tentang tujuan-tujuan bersama. Tokoh yang paling dianggap berjasa dalam teori pilihan rasional ini adalah Kenneth Arrow karena menyebabkan paradigma pilihan rasional ini mendapat tempat dalam ilmu ekonomi politik.

Dalam perkembanganya teori pilihan rasional yang dikembangkan oleh James Buchaman dan Gordon Tullock dalam Calculus of Consent (1962). Karya mereka menjadi batu loncatan dalam memahami teori pilihan publik. Definisi tentang Public Choise Theory disederhanakan pada tahun 1995. Menurut (Samuelson \& Nordhaus dalam Deliarnov, 2006: 139) mendefinisikan pilihan public sebagai asks about how, what dan for of the public sectors just as supply and demand theory examines choices for the private sectors". Pertanyaan tentang bagaimana, apa dan untuk sektor-sektor publik hanya sebagai penawaran dan permintaan teori pilihan untuk sektor private.

Sementara itu (Caporaso \& Levine dalam Deliarnov, 2006: 139), mendefinisikan pilihan publik 
sebagai aplikasi metode-metode ekonomi terhadap politik. Pendapat Caporaso dan Levine lebih mirip dengan penpadat James Buchanan melihat bahwa teori pilihan publik itu menggunakan alat-alat dan metode-metode yang diaplikasikan ke sektor politik, pemerintahan, ilmu politik atau ekonomi publik. Lebih sederhana (Rachbini, 1996) menafsirkan pendapat Buchanan tentang definisi pilihan publik adalah sebuah perspektif untuk bidang sosial politik yang muncul dari pengembangan dan penerapan perangkat dan metode ilmu ekonomi.

Dengan demikian, Teori Pilihan Publik menggunakan prinsip yang sama seperti yang digunakan para ekonom untuk menganalisa kegiatan masyarakat di pasar dan menerapkannya pada kegiatan masyarakat dalam pembuatan keputusan publik. Ekonom-ekonom yang mengkaji perilaku dalam pasar swasta mengasumsikan bahwa orang digerakkan terutama oleh kepentingan pribadi. Walaupun banyak orang mendasarkan sejumlah tindakan mereka karena kepedulian mereka terhadap orang lain, motif dominan dalam tindakan orang di pasar -baik mereka merupakan, pengusaha, pekerja, maupun konsumen, adalah suatu kepedulian terhadap diri mereka sendiri. Ahli Ekonomi Pilihan Publik membuat asumsi yang sama bahwa walaupun orang bertindak dalam pasar politis memiliki sejumlah kepedulian terhadap orang lain, motif utama mereka adalah kepentingan pribadi.
Teori pilihan publik berusaha mengkaji tindakan rasional dari aktor-aktor pembuat kebijakan, pelaksana kebijakan dari tingkat di parlemen, lembaga pemerintah, lembaga kepresidenan, masyarakat pemilih, pencinta lingkungan hidup dan sebagainya.

Buchanan

(dalam

Rachbini,2006:69) memandang pilihan publik sebagai sebuah perspektif untuk bidang'sosial politik yang muncul dari pengembangan dan penerapan perangkat dan metode ilmu ekonorni. Teori pilihan publik, ini berguna untuk menjelaskan proses pengambilan keputusan kolektif dan berbagai fenomena nonpasar (nonmarket phenomena).

Fenomena Pelayanan Transportasi Publik dan Pilihan yang Terbatas

Persoalan transportasi publik di negara-negara berkembang, sejatinya mempunyai persoalan yang relatif sama yaitu masalah kemacetan, keselamatan pengguna jasa dan buruknya fasilitas sering dijumpai dinegara tersebut. Di Pakistan, seperti halnya di Indonesia kebijakan terhadap sektor tarnsportasi selalu menjadi pelik. Pada satu sisi agen-agen pemerintah, _di Indonesia bisa dilihat sebagai BUMN_ mempunyai peran yang cukup menonjol dalam mengontrol keberadaan dan operasional transportasi publik. Hasil penelitian yang dilakukan Imran di Pakistan menunjukkan bahwa kebijakan privatisasi di Pakistan mengalami kegagalan. Imran memulai penelitiannya dengan abstraksi yang 
mengatakan persoalan-persoalan transportasi masyarakat urban adalah bagaimana mengatur pembangunan yang besar dan pembangunan jalanjalan yang lebih baik. Berikut kutipan (Imran, 2010:77)

The presence of mixed land use, high population and employment density, and growing needs of motorized transport use in Pakistani cities shows a potential to establish a multimodal transport system at metropolitan level. In Pakistani cities, public transport has traditionally been provided by buses, while rail-based public transport existed primarily at the intercity level. Pakistani cities have an opportunity to convert existing intercity railway into urban rail network and buses into light rail or highcapacity trolley buses with dedicated right-of-way. Pakistani cities clearly need a hierarchy of public transport modes that can carry a large to small number of passengers in different times of the day in a well-coordinated network. the multimodal public transport system has potential to play a catalytic role in the regeneration of Pakistani cities and discontinuation of the urban sprawl.

Di Pakistan terdapat sesuatu yang dianggap kontras jika dibandingkan dengan prinsip-prinsip transportasi berkelanjutan

(sustainable transport) yang mengajur biaya yang rendah pada transportasi publik, dalam melaksanakan kegiatan tersebut di jalan yang kacau dan kemacetan yang tinggi di kota-kota pakistan. Penelitian Imam sejatinya mengkaji secara kritis perkembagan transportasi di Pakistan sejak British India Periode sampai saat ini. Yang jadi fokusnya problemnya adalah bagaimana membangun dan mengatur sistem transportasi mereka yang berdasar pada level mobilitas tinggi, berkeadilan dan terusmenerus sesuai dengan lingkungan sekitarnya. Kota Pakistan membutuhkan moda transportasi umum yang dapat membawa masyarakat dengan jumlah yang besar pada waktu yang sama dengan jaringan yang koordinasi dengan baik. Bagaimanapun, sistem multimuda angkutan umum disana belum mampu memberikan peran katalisator dalam peremajaan kota pakistan atau daerah urban, dengan kata lain masih terlihat kumuh.

Sementara penelitian di Oman, hasil Penelitian yang dilakukan dimulai dengan pernyataan bahwa dibanyak negara, termasuk Oman, butuh transpotasi yang baik sebagai opsi berpergian setelah warga negara sering kesulitan untuk memperoleh share kendaraan, kecuali dengan taxi atau kendaraan pribadi. Perilaku masyarakat disana terhadap transportasi dijelaskan (Belwal and Belwal, 2010:17): 
"Behavior reveals that a majority of them use their personal cars to get to work and only a few use public transport services. It is not that the people in Oman have not experienced public transport services in the past. They have, but their experience with public transport services has not been pleasant.... The testing of hypotheses reveals that people consider public transportation important for society and believe that public transport is convenient and cost effective. People do not feel any discomfort in sharing taxis/buses with others. People find some sociocultural barriers affecting the use of public transport in Oman. They prefer to travel by their own cars and are sufficiently convinced of the merit of this mode of travel even if the price of oil doubles in Oman. However, they are willing to use public transport provided good transport infrastructure is developed.

Banyaknya solusi, bahwa kebutuhan dan ekspektasi orangorang terhadap kendaraan terdepan (utama) telah memaksa untuk mengunakan biaya yang tinggi. Dalam penelitiannya yang menggunakan cara survei, menunjukkan bahwa masyrakarat Oman tidaklah familier dengan adanya transportasi publik. Mayoritas masyarakatnya menggunakan kendaraan atau mobil pribadi untuk keperluan mereka masing-masing. Hanya sedikit saja masyarakat Oman yang tergantung pada transportasi publik. Lalu bagaimana dengan di Indonesia?

Di Indonesia, sistem transportasi publik juga mempunyai kemiripan dengan Pakistan, terutama dalam hal transportasi publik- darat. Kebijakan transportasi publik, menempatkan pemerintah sebagai pemilik dan pelaksana. Tetapi disisi lain, pemerintah memberikan wewenangnya untuk pihak swasta ikut serta mengelolah transportasi, khusus angkutan darat ada beberapa perusahaan yang beroperasi pada bidang transportasi, biasanya mereka tergabung dalam organisasi tertentu untuk menguatkan diri seperti Organda, misalnya.

Secara konseptul, persyaratan yang digariskan dalam managarialism paradigms bukanya tidak dilakukan. Aliran ini menganjurkan untuk mengurangi campur-tangan pemerintah dalam memberikan pelayanan kepada publik. Alasanya sederhana saja, yaitu dengan menyerahkan wewenangnya kepada pihak ketiga persoalan pelayanan dapat teratasi dengan baik. Dengan pelimpahan ke pihak ketiga, pelayanan coba didekatkan sedekat mugnkin ke publik. Dalam kasus transportasi publik, pemerintah telah sejak lama membuka seluas-luasnya partisipasi dari pihak swasta untuk turut serta sebagai penyelenggara transportasi. Dimana pelayanannya sepenuhnya 
diserahkan kepada operator yang bersangkutan. Namun soal mutu pelayanan tunggu dulu, secara umum operator swasta maupun yang dikelolah pihak pemerintah tidak jauh berbeda yaitu mutunya masih rendah, berjubel, tidak nyaman dan tidak aman. Problemnya adalah sejatinya banyak pengelolah transportasi yang berkerja kurang profesional. Jika penyedia transportasi bekerja secara profesional sejatinya akan menumbuhkan persaingan yang sehat.

Jika persaingan sehat tercipta, publik mempunyai kesempatan untuk memperoleh pelayanan yang maksimal karena mempunyai banyak pilihan. Dari segi penyelenggara (operator) bisa meningkat pelayanan dan tidak sewenang- wenang dalam memberikan tarif dan pelayanan. Kondisi demikian akan memunculkan proses tawarmenawar, dimana disana ada supply and demand. Jika ada penawaran pasti ada permintaan. Setiap penawaran akan dilihat dari seberapa baik barang yang ditawaran. Dengan kata lain, penawar mempunyai hak untuk memilih dalam hal apa mereka tertarik dan hal bagaimana mereka menggunakan barang tersebut. Dalam konteks transportasi, pengguna transportasi akan berpikir jika mereka mampu dan bisa membeli kendaraan pribadi yang baik dan nyaman sudah barang tentu mereka akan memilih kendaraan pribadi.
Asumsi dari transportasi yang baik_transportasi yang nyaman, aman, cepat dan mempunyai akses yang luas ke semua tempat_ publik akan beralih dari kendaraan pribadi ke transportasi publik. Dengan semakin padatnya jalan, dengan semakin lemah daya tampung jalan dan semakin terbatasnya lahan dalam membangun jalan raya baru, menurut penulis kebijakan transportasi seperti Bus Rapit Transit (BRT) atau Train Rapit Transit (TRT) system merupakan pilihan yang rasional. Jika sistem ini dilakukan dengan baik maka konsumen secara otomatis akan berlaih. Dengan kata lain Bus Rapit Transit (BRT) atau Train Rapit Transit (TRT) system dibangun kepada semua kalangan baik kelas atas maupun kelas bawah. Operator dari dua sistem ini, bisa dilakukan oleh pemerintah atau swasta.

Dalam konteks Indonesia, Bus Rapit Transit (BRT) atau Train Rapit Transit (TRT) sistem sejatinya cikal-bakalnya sudah ada, kereta api ataupun trans jakarta sebagai contoh. Persoalannya baik pihak swasta maupun operator pemerintah mengalami delima yang sama terhadap armada mereka. Yaitu armada yang ada tidak perform dalam memberikan pelayananan kepada pelanggan. Situasi ini bertambah parah, dengan pesatnya pertumbuhan kendaraan pribadi. Salah satunya sebabnya tingginya biaya operasional akibat krisis ekonomi memaksa semua armada_ baik swasta maupun BMUN_ melakukan strategi kanibalisasi. 
Problem lain dari situasi tersebut di atas adalah semakin padatnya arus dijalan raya. Jalan raya disini merupakan bagian dari public good. Dimana keberadaanya disediakan oleh negara, siapapun bisa menggunakannya. Dengan semakin padatnya jalan raya, menjadi perlu untuk melakukan kebijakan alternatif, melakukan langkah terobosan guna mengurangi ketergantungan warga negara pada jalan raya.

Selama ini, pemerintah bukannya belum menggunakan Bus Rapit Transit (BRT) atau Train Rapit Transit (TRT) system _dengan segala keterbatasannya tentunya_ tetapi pada kenyataannya tidak semua warga negara familier dan nyaman dengan transportasi tersebut. Ada kesadaran dari pihak pemerintah bahwa Bus Rapit Transit (BRT) atau Train Rapit Transit (TRT) system adalah alternatif transportasi publik. Buktinya, dalam satu tahun terakhir ini telah terjadi beberapa perubahan dalam pengelolahan. Sebagai contoh kereta api sebagai angkutan massa semakin kenyamanan bagi penumpang seperti ketentuan larangan merokok, atau adanya tempat duduk bagi penumpang bahkan untuk kelas ekonomi sekalipun.

Lebih jauh, pengajian terhadap keberadaan transportasi publik dikaitkan dengan teori public choise. Intinya adalah bahwa kebijakan transportasi publik itu dapat dilihat sebagai Catallaxy. Ditengah kemacetan yang begitu krodit, keberadaan transportasi publik berupa Bus Rapit Transit (BRT) atau Train Rapit Transit (TRT) system bisa dipandang sebagai institusi pertukaran yang melibatkan warga negara disatu sisi dan pengelolah transportasi publik disisi yang lain dengan kedua-belah pihak memperoleh keuntungan. Pengguna jasa transpotasi publik merasa akan lebih efesien karena ada kepastian keteapatan waktu, kenyaman dan keselamatan sementara pengelolah diuntungkan dengan semakinnya banyaknya penumpang. Intinya, dari segi income, pengelolah transportasi publik cukup mengalami peningkatan.

Sementara itu, konsep Catallaxy ini agak sedikit sulit_meskipun itu masih memungkinkan_ diterapkan jika dikaitkan dengan persoalan pembangunan infrastruktur di daerah perkotaan dan padat penduduk. Seharusnya jika menggunakan konsep ini, pembebasan lawan untuk membuat rel kereta yang modern tidak persoalan karena akan terjadi spontanitas dan konsesus sukarela. Ini menunjukkan bahwa konsepkonep yang ada lam catallaxy ini tetaplah konsep yang berdasarkan kepentingan ekonomi. Jadi, syarat terjadinya konsensus adalah dengan adanya kesepakatan harga dalam melakukan barter.

Selanjutnya, kita bisa menggunakan konsep manusia sebagai mahluk ekonomi (homo economicus), konsep ini 
menunjukkan bahwa setiap orang mempunyai kepentingan ekonomi dalam arti yang positif. Dalam konteks kebijakan transportasi publik kereta api, menunjukkan bahwa motif-motif kebijakan seperti disebut di atas adalah motif kepentingan ekonomi semata. Dari sudut pandang PT. KAI, misalnya, apa yang dilakukan dengan memperbaiki fasilitas dan pelayanan demi keuntungan perusahaaan, yang pada akhirnya akan meningkatkan gaji para karyawan PT. KAI. Sementara dari sudut pandang pelanggan, mereka mempunyai hak untuk memilih, bahwa pilihan mereka harus menggunakan ongkos yang lebih itu tidak persoalan sepanjang mereka merasa puas dengan pelayanan.

\section{Kesimpulan}

Persoalan

kebijakan

transportasi publik di Indonesia merupakan persoalan yang sama yang juga menimpah beberapa negera-negara berkembang lainya, khusunya di beberapa negara Asia. Kondisi transportasi di Indonesia, khususnya transportasi darat cukup memperhatinkan. Padahal, para pengguna jasa transportasi darat cukup besar meskipun pertumbuhan kendaraan pribadi tidak kalah pesatnya. Kedepan diperlukan sebuah jenis transportasi yang bisa mengangkut penumpang dengan skala yang besar. Yaitu alternatif transportasi massal yang menekankan pada volume penumpang seperti kereta api, Bus
Rapit Transit (BRT) atau Train Rapit Transit (TRT) system.

Perbaikan fasilitas dan infrastruktur mutlak diperlukan, untuk meningkatkan pelayanan kepada pengguna transportasi publik. Seringkali, fasilitas dan infrastruktur dihiraukan oleh pengelolah transportasi sehingga banyak pelanggan yang memilih menggunakan kendaraan pribadi demi kenyamanan, keamanan dan kelincahan dalam melakukan mobilisasi. Dalam Mengatasi kemacetan, perlu kiranya pihak pemerintah mempersulit keberadaan kendaraan bermotor yang dimiliki secara pribadi dengan mempertinggi pajak kendaraan. Atau Pemerintah memperketat perkreditan kendaraan.

\section{Daftar Pustaka}

Andrisani, P.J., Hakim, S. And Savas, E.S., 2002. The New Public Management: Lessons From Innovating Governors and Mayors, Kluwer, Massachusetts

Belwal, R and Belwal, S. 2010 Public Transportation Services in Oman: A Study of Public Perceptions, Oman Journal of Public Transportation, Vol. 13, No. 4, 2010

Buchanan J. M and Tollison R.D. 2009. The Theory Of Public Choice -II,The University of Michigan Press

Cullen, R.B. and Chusman, D.P., 2000. Transitions to 
Competitive Government,

State University of New York

Press, Albany

Deliarnov, 2006. Ekonomi Politik.

Surabaya. Penerbit Erlangga

Denhardt , Janet V Dan Denhardt,

Robert B. 2003. The New

Public Service, Serving, Not

Sreering. New York. M.E

Sharpe

Dirjen Perhubungan Darat, 2006.

Masterplan

Transportasi

Darat. Jakarta :Departemen

Perhubungan

(http://www.dephub.go.id/)

diakses tanggal 122012

Dirjen Perkeretaapin, 2010. Rencana

Strategis

2010-2014

Kementerian Perhubungan

Bidang

Perkeretaapian.Jakarta:

Kementerian Perhubungan.

http://perkeretaapian.deph

ub.go.id diakses 12

November 2012

Imran, Muhammad. 2009. Public

Transport in Pakistan:A

Critical Overview. Journal of

Public Transportation, Vol.

12, No. 2 ,

LMFEUI,2008. Analisa Angkutan

Kereta Api dan Implikasinya pada BUMN Perkeretapian Indonesia. Jakarta, FE.UI Press

Lynn, L.E., 2006. Public

Management : Old and New,

Routledge, New York.

Martin, Saint.D, 2000. Building the

New Managerialist State,

Oxford University Press,

Oxford.
Moleong, Lexy, J. 2006. Metode

Penelitian Kualitatif. Bandung.

Remaja Rosdakarya.

Munawar, Ahmad, 2007.

Pengembagan Transportasi

Yang Berkelanjutan (Pidato

Pengukuhan Guru Besar).

Yogyakarta.Universitas

Gajdah Mada

Milward, H. Brinton and Provan, Keith G. 2000. Governing the Hollow State . Journal of Public Administration Research and Theory

Osborne, Stephen P. 2010. The Public Governance? Emerging perspectives on the Theory and Practice of Public Governance. New York and London. Routledge, Taylor and Francis Group

Peters, Shophia C. 2011. Bringing in the Peri-Urban Poor: Options for Expanding Mexico City's Transportation Network, Sanford Journal of Public Policy, Vol. 2, Iss. 1

Rachbini, Didik J,2006. Ekonomi Politik dan Teori Pilihan Publik (Edisi Kedua). Depok: Ghalia Indonesia

Rachbini, Didik.J. 1996. Ekonomi

Politik: paradigm, teori, dan perspektif baru. Jakarta: CIDES.

Transportasi, Tim Penyusun. 2006. Transportasi 2005-2025, Buku Putih. Jakarta: Kementerian Perhubungan

UU No. 22 tahun 2009 tentang Keselamatan Lalu Lintas dan Angkutan Jalan 
(www.pikiran-rakyat.com.

Kecelakaan Lalu Lintas Terus

Meningkat. $14 / 02 / 2012)$

diakses 15 Desember 2012.

http://www.republika.co.id/berita/reg

ional/jabodetabek diakses 16

November 2012

http://vibiznews.com/news/banking_i nsurance/2011/08/01/ bi- tetapkan-kebijakan-loan-to-

value-untuk-kredit-

kendaraan-bermotor diakses

29 November 2012

http://perkeretaapian.dephub.go.id/

Rencana Strategis Kementerian

Perhubungan 2010-2014, Bidang

Perkereta Apian diakses 12

Desember 2012. 